\title{
Surface active substances in the upper water column during a Southern Ocean Iron Fertilization Experiment (EIFEX)
}

\author{
P. L. Croot, ${ }^{1}$ U. Passow, ${ }^{2}$ P. Assmy, ${ }^{2}$ S. Jansen, ${ }^{2}$ and V. H. Strass ${ }^{2}$ \\ Received 5 September 2006; revised 10 January 2007; accepted 18 January 2007; published 15 February 2007.
}

[1] Surface active substances (SAS) in the water column were measured by voltammetry using the electrochemical probe $o$-nitrophenol (ONP) during EIFEX, a mesoscale open ocean iron enrichment experiment in the Southern Ocean. SAS levels were low throughout the experiment $\left(<0.005-0.03 \mathrm{mg} \mathrm{L}^{-1}\right.$ Triton X-100 equivalents). Initially SAS was extremely low in the photic zone, but as the phytoplankton bloom developed concentrations markedly increased throughout the upper $100 \mathrm{~m}\left(\sim 0.02 \mathrm{mg} \mathrm{L}^{-1}\right.$ Triton X-100 equivalents). Highest concentrations of SAS $\left(>0.02 \mathrm{mg} \mathrm{L}^{-1}\right.$ Triton X-100 equivalents) were found at the end of the bloom particularly at density discontinuities where organic material may accumulate. Exudates from diatoms appeared to be the major source of SAS during EIFEX, either from direct extracellular release or in the action of being grazed upon by zooplankton. Citation: Croot, P. L., U. Passow, P. Assmy, S. Jansen, and V. H. Strass (2007), Surface active substances in the upper water column during a Southern Ocean Iron Fertilization Experiment (EIFEX), Geophys. Res. Lett., 34, L03612, doi:10.1029/ 2006GL028080.

\section{Introduction}

[2] Amongst the wide variety of dissolved organic molecules present in seawater are an important subset with surface active properties [Hunter and Liss, 1981]. These molecules typically possess structural groups with affinity for water while also containing other structural groups that are hydrophobic in nature; as such these molecules tend to accumulate by adsorption processes at water phase boundaries. In this manner SAS influences numerous geochemical and physical processes in the ocean. The presence of SAS in the sea surface micro-layer can significantly decrease air-sea exchange rates of dissolved gases [Frew et al., 1990; Tsai and Liu, 2003]. Surfactants can also alter the equilibrium between the dissolved and particulate phases for many trace metals [Shine and Wallace, 1996] and enhance the aggregation of small colloids and particles, leading to increased sinking fluxes [Mopper et al., 1995; Zhou et al., 1998]. The source of these surfactants is presumed to be primarily from phytoplankton exudates and their degradation products either by direct production [Zutic et al., 1981] or from zooplankton grazing [Kujawinski et al., 2002] with large concentrations of surfactants often being observed during phytoplankton

\footnotetext{
${ }^{1}$ Forschungsbereich Marine Biogeochemie, Leibniz-Institut für Meereswissenschaften at University of Kiel, Kiel, Germany.

${ }^{2}$ Alfred Wegener Institute for Polar and Marine Research, Bremerhaven, Germany.

Copyright 2007 by the American Geophysical Union. 0094-8276/07/2006GL028080\$05.00
}

blooms in coastal waters [Gašparović and Ćosović, 2001; Gašparović et al., 1998a]. The composition of the surfaceactive material is strongly influenced by the dominant phytoplankton [Gašparović et al., 1998b] and is mostly comprised of polysaccharide compounds [Passow et al., 1994] but also includes biologically derived lipids and proteins.

[3] In the present work samples from the upper water column $(0-300 \mathrm{~m})$ were measured for SAS during the course of the European Iron Fertilization Experiment (EIFEX: R/V Polarstern cruise ANT XXI/3) in the Atlantic sector of the Southern Ocean from 9 Feb to 21 March 2004 [Smetacek et al., 2005]. This work was performed to complement other data sets collected during EIFEX (papers in preparation) on: (1) transparent exopolymer particles (TEP), in which SAS may be precursor compounds [Passow, 2000; Zhou et al., 1998]; and (2) trace metal data, where SAS may affect the removal rates and speciation of certain metals in the water column [Wallace, 1982] and in the sea surface microlayer [Hardy et al., 1985; Hunter, 1980]. This work represents the first measurements of SAS during an open ocean iron induced phytoplankton bloom.

\section{EIFEX Setting}

[4] The EIFEX study was performed in a mesoscale cyclonic eddy, embedded in a meander of the Antarctic Polar Front [Strass et al., 2005]. The eddy was approximately $90 \times$ $120 \mathrm{~km}$ in scale centered on $49.4^{\circ} \mathrm{S}, 2.25^{\circ} \mathrm{E}$. The initial fertilization was performed on $12-13$ February 2004 by the addition of $7000 \mathrm{~kg}$ of iron sulfate (FeSO4 $\cdot 7 \mathrm{H}_{2} \mathrm{O}$ ) as an acidic slurry into the mixed layer. The fertilized area was a spiral around the eddy centre, corrected for lagrangian drift, as determined by a GPS-buoy released immediately prior to the release of the $\mathrm{Fe}$. The initial fertilization area was approximately $150 \mathrm{~km}^{2}$. After two weeks with dissolved Fe concentrations approaching pre-infusion levels a second infusion of $7000 \mathrm{~kg}$ of iron sulfate took place within the previously enriched patch as defined by the photosynthetic activity Fv/Fm [Röttgers et al., 2005] as measured by FastRepetition-Rate-Fluorescence (FastTracka, Chelsea, UK). All sampling sites reported in this manuscript were located in the eddy; stations within the fertilized waters are hereafter described as in-patch and those from outside as out-patch. Identification of stations as being in or out of the fertilized patch was assessed based on several key criteria: iron concentration, $\mathrm{Fv} / \mathrm{Fm}, \mathrm{pCO}_{2}$ and chlorophyll [Smetacek et al., 2005].

\section{Methodology}

[5] Electrochemical methods utilizing o-nitrophenol (ONP) as a probe for the rough characterization of organic 
Table 1. Station Information for EIFEX Surfactant Sampling

\begin{tabular}{lcccc}
\hline \multicolumn{1}{c}{ Station } & Date $^{\mathrm{a}}$ & Time, UTC & Latitude & Longitude \\
\hline 425 - Fe Infusion & $12 / 2 / 2004(0)$ & $13: 15$ & $49.4^{\circ} \mathrm{S}$ & $2.25^{\circ} \mathrm{E}$ \\
427 IN/OUT & $13 / 2 / 2004(1)$ & $19: 05$ & $49^{\circ} 12.01^{\prime} \mathrm{S}$ & $02^{\circ} 04.99^{\prime} \mathrm{E}$ \\
508 & $22 / 2 / 2004(10)$ & $07: 53$ & $49^{\circ} 12.14^{\prime} \mathrm{S}$ & $02^{\circ} 00.44^{\prime} \mathrm{E}$ \\
512 - Fe Infusion & $26 / 2 / 2004(14)$ & $12: 31$ & $49^{\circ} 38.7^{\prime} \mathrm{S}$ & $02^{\circ} 30.1^{\prime} \mathrm{E}$ \\
514 OUT & $29 / 2 / 2004(17)$ & $17: 53$ & $49^{\circ} 15.42^{\prime} \mathrm{S}$ & $02^{\circ} 20.14^{\prime} \mathrm{E}$ \\
543 & $04 / 3 / 2004(21)$ & $06: 54$ & $49^{\circ} 28.76^{\prime} \mathrm{S}$ & $02^{\circ} 27.32^{\prime} \mathrm{E}$ \\
570 & $14 / 3 / 2004(31)$ & $02: 17$ & $49^{\circ} 25.74^{\prime} \mathrm{S}$ & $02^{\circ} 03.17^{\prime} \mathrm{E}$ \\
580 & $16 / 3 / 2004(33)$ & $02: 28$ & $49^{\circ} 07.88^{\prime} \mathrm{S}$ & $02^{\circ} 15.21^{\prime} \mathrm{E}$ \\
\hline
\end{tabular}

${ }^{a}$ The number in parentheses indicates the number of days after the first infusion began, the numbers are rounded to the nearest integer value.

${ }^{\mathrm{b}}$ Station 427 was sampled immediately after the initial Fe fertilization and is thus used here as the initial time point (data not shown in Figure 1, SAS concentrations were at or below the detection limit: SAS $<0.005 \mathrm{mg} \mathrm{L}^{-1}$ Triton X-100 eq).

matter in seawater have been developed in a series of papers by Gašparović, Ćosović and Vojvodić [Gašparović and Cosović, 1994, 1995, 2001; Gašparović et al., 1997, 1998a, 1998b]. In the present work SAS was determined with Alternating Current -Voltammetry (in-phase mode) with a Metrohm VA 757 voltammeter using ONP as a probe compound [Gašparović et al., 1998a]. Standards, using Triton X-100 as the external standard, were run in samples of deep seawater (1500 m - low surfactants) which had previously been UV oxidized (Metrohm UV-Digestor 705) to remove organic material (see Text S1 in the auxiliary material). ${ }^{1}$ To avoid contamination from surfactants present in the sea surface microlayer, samples were collected from GO-FLO (General Oceanics Model 1080) sampling bottles deployed on a trace metal clean hydrowire (Aramid). Filtered (acid-cleaned $0.2 \mu \mathrm{m}$ Sartorius cartridge filter) samples were drawn into ethanol rinsed polyethylene vials and kept at $4^{\circ} \mathrm{C}$ (in situ temperature) in the dark until analysis. Aliquots $(20 \mathrm{~mL})$ of the seawater samples were spiked with ONP in solvent (HPLC grade - ethanol) cleaned Quartz or Teflon cell cups. The samples were purged with dry $\mathrm{N}_{2}$ gas for 3 minutes and pre-concentrated on the $\mathrm{Hg}$ drop for deposition times of $0,60,180$ and $300 \mathrm{~s}$.

[6] Hydrographic data from each station was collected from separate conductivity-temperature-depth (CTD) casts using a Seabird SBE911plus (Seabird Electronics) with a 24-bottle water sampler (General Oceanics). The instruments were calibrated immediately before and after the cruise. For in situ calibration, temperatures were measured with reversing thermometers, and salinity samples were analyzed with a Guildline-Autosal-8400A salinometer onboard.

[7] The composition of the phytoplankton community during EIFEX was assessed by light microscopy. Water samples of $200 \mathrm{~mL}$ were obtained from the CTD rosette from 7 depths between 10 and $150 \mathrm{~m}$ for the quantitative assessment of the diatom assemblage. Samples were preserved with hexamine-buffered formaldehyde solution (2\%) and stored at $4^{\circ} \mathrm{C}$ in the dark for subsequent counting in the home laboratory. A volume of $50 \mathrm{~mL}$ was settled in sedimentation chambers (Hydrobios, Kiel, Germany) for 48 hours. Cells were identified and enumerated using inverted light and epifluorescence microscopes (Axiovert 135 and Axiovert 200, Zeiss, Oberkochen, Germany) according to Utermöhl [1958]. Bio-volume was calculated from equivalent geometrical shapes [Hillebrand et al., 1999] and converted to cellular carbon content through recom-

\footnotetext{
${ }^{1}$ Auxiliary materials are available in the HTML. doi:10.1029/ 2006GL028080.
}

mended carbon conversion equations [Menden-Deuer and Lessard, 2000]. Biomass of all species described here are trapezoidal depth-integrated values for the upper 0-100 $\mathrm{m}$ of the water column.

\section{Results and Discussion}

\subsection{Water Column Surfactants During EIFEX}

[8] Samples were collected and analyzed onboard during EIFEX from 6 stations during the course of the phytoplankton bloom (Table 1 and Figure 1). The concentration of SAS was extremely low initially at both the in and the out stations throughout the water column $\left(<0.005 \mathrm{mg} \mathrm{L}^{-1}\right.$ Triton X-100 equivalents). SAS was lower than published data from the Adriatic [Gaśparović and Ćosović, 2001] and sub-Arctic Fjords [Gašparović et al., 2005], as might be expected for an open ocean, deep mixed layer, low chlorophyll location. SAS levels increased sharply at depth around day 10 , prior to the 2 nd infusion (day 14) but were still low outside the patch (day 17). As the experiment progressed there was an increase in SAS $\left(\sim 0.02 \mathrm{mg} \mathrm{L}^{-1}\right.$ Triton X-100 eq) throughout the upper water column (day 21). For the last week of observations of the EIFEX patch, enhanced levels $\left(\sim 0.03 \mathrm{mg} \mathrm{L}^{-1}\right.$ Triton X-100 eq) of surfactant activity where found in the water column immediately below the shallowing active mixed layer (AML) (as defined in Brainerd and Gregg [1995]), similarly enhanced levels where also found at depths below the mixed layer (Figure 1).

\subsection{Development of the EIFEX Bloom}

[9] During the course of EIFEX chlorophyll $a$ concentrations increased roughly 6 fold up to 26 days after the initial infusion and then began to decrease [Hoffmann et al., 2006]. The Fe addition saw a dramatic increase in the numbers and biomass of diatoms (Figure 2) in all size classes while other algal classes remained relatively static, with the exception of a small increase in Phaeocystis sp. [Hoffmann et al., 2006]. Towards the end of the experiment there was an apparently rapid export of organic matter from the mixed layer to deeper waters as evidenced by the presence of both the diatom marker fucoxanthin and low phaeopigment to chlorophyll ratios in samples collected throughout a water column of $4000 \mathrm{~m}$ [Peeken et al., 2005]. This sinking organic matter was in part comprised of particular diatom species like Chaetoceros dichaeta whose biomass in the upper water column at this time decreased rapidly (Figure 2). The presence of particle aggregates below the mixed layer was also seen as spikes in the fluorescence and transmission (not shown) profiles at this time (Figure 1). 

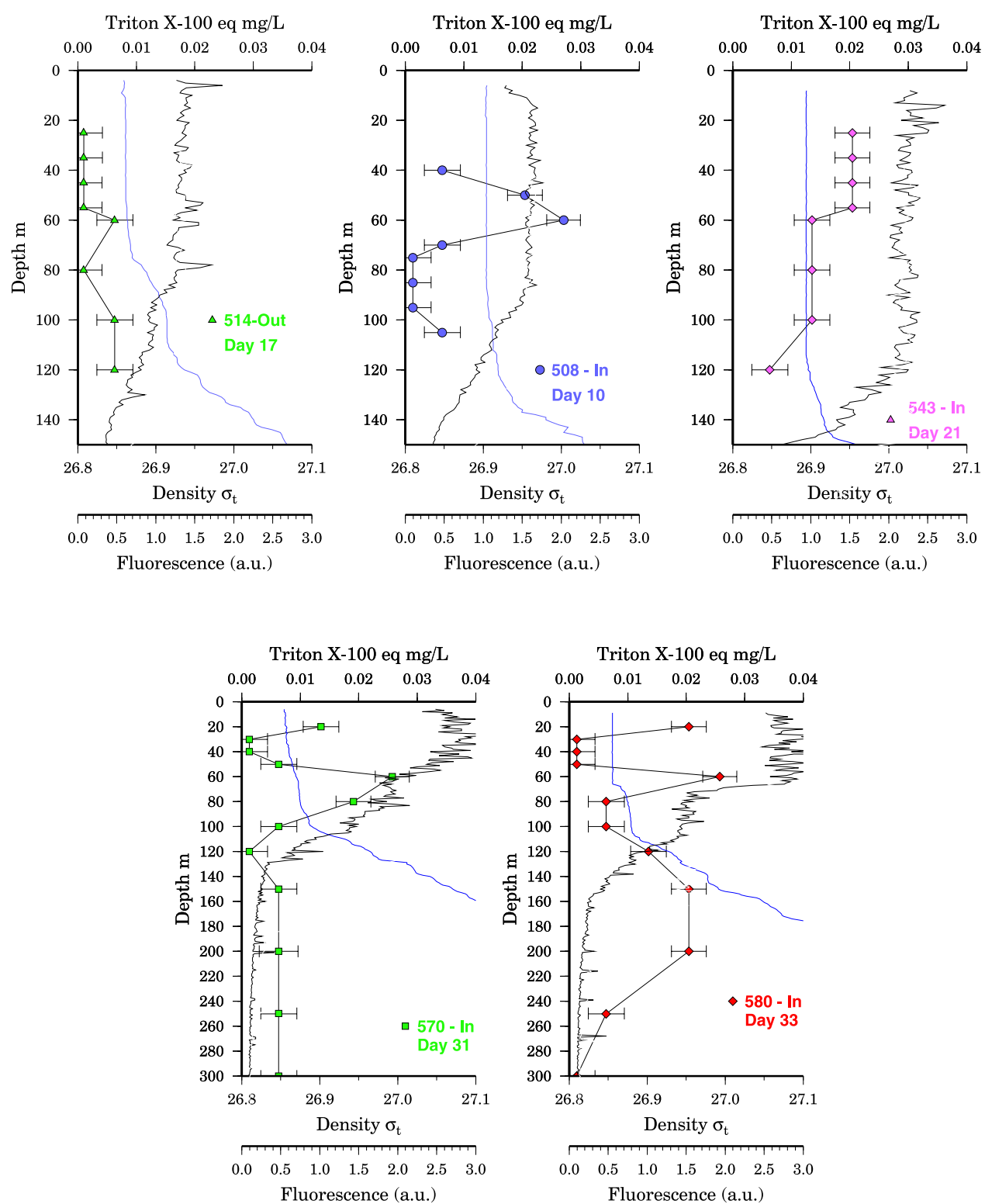

Figure 1. Temporal development of the vertical profile of SAS (symbols) in the water column during EIFEX. (top left) Station 514 (green triangles - OUT patch). (top middle) Stations 508 (blue circles -10 days after 1st infusion). (top right) Station 543 (pink diamonds - 21 days after the 1st Fe infusion). (bottom left) Station 570 (green squares - 31 days after the 1 st Fe infusion). (bottom right) Station 580 (red diamonds - 33 days after the 1st Fe infusion). Density profiles (solid blue lines) and fluorescence profiles (solid black lines) are also shown for each station to indicate the MLD and the distribution of phytoplankton at this time. Data from station 427 is not shown as the SAS concentrations were at or below the detection limit $\left(0.001 \mathrm{mg} \mathrm{L}^{-1}\right.$ Triton X-100 eq). Note the scale change in the depth for the last two stations.

[10] Over the course of EIFEX the upper water column inventory of SAS $(0-100 \mathrm{~m}$ : calculated using the trapezoidal rule) of the Fe fertilized patch apparently increased over the first 20 days and then slightly decreased afterwards (Figure 2). The only out station sampled (day 17) still had low integrated SAS concentrations similar to the in patch initial conditions.

\subsection{Enhanced SAS at Density Discontinuities}

[11] Although SAS is thought to be produced by phytoplankton [Zutic et al., 1981] the vertical distribution pattern did not reflect bulk fluorescence or chlorophyll profiles. A strong feature in the vertical profiles (Figure 1) is the presence of zones of high SAS that are often aligned with small steps in the CTD derived density profiles. This phenomena is most notably for days $31-33$ at which time the AML had decreased due to a slight warming (density decrease) of the near surface waters. This enrichment in SAS may arise from accumulation of phytoplankton source material at density discontinuities [MacIntyre et al., 1995]. An additional important factor in the case of samples below $50 \mathrm{~m}$ from both day 31 and 33 is that this depth is now below the $1 \%$ light level (approximately $40 \mathrm{~m}$ ) at this time. Thus phytoplankton in turbulent overturns below the AML would no longer be mixed above the $1 \%$ light level and thus maybe light limited; a situation for some diatom species that 

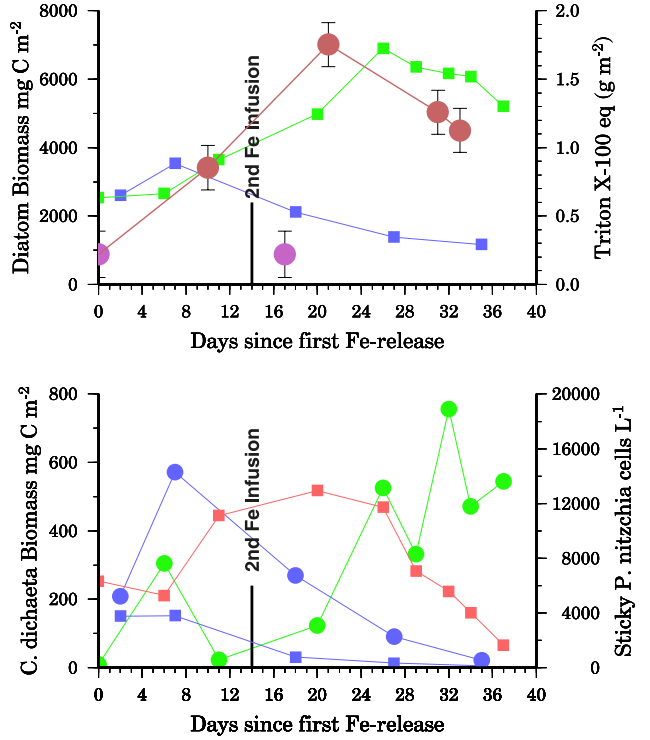

Figure 2. (top) Water column inventories (top $100 \mathrm{~m}$ ) of the estimated total diatom biomass (squares: green, in patch; blue, out patch) and SAS (circles: red, in patch; purple, out patch), expressed as Triton X-100 equivalents, during EIFEX. The initial SAS inventory from station 427 is estimated as 3 times the detection limit $\left(0.001 \mathrm{mg} \mathrm{L}^{-1}\right.$ Triton X-100 eq) multiplied by the water column depth $(100 \mathrm{~m})$ giving rise to an estimate of $0.3 \pm 0.2 \mathrm{~g} \mathrm{~m}^{-2}$ of Triton X-100 eq (95\% confidence interval). (bottom) Average abundance (top $100 \mathrm{~m}$ ) of 'sticky' Pseudo-nitzchia sp. (circles: green, in patch; blue, out patch) and the estimated biomass for the diatom Chaetoceros dichaeta (squares: red, in patch; blue, out patch). Both were determined from direct microscopy counts.

leads to an increased release of organic exudates [Ignatiades and Fogg, 1973], which potentially may include SAS.

[12] The increase in SAS below the AML through the depth range $100-300 \mathrm{~m}$ is not consistent with the diffusion of a dissolved substance in water at this time. Typical diffusion rates for below the mixed layer in this region of the Antarctic [Cisewski et al., 2005] are $10^{-4}-10^{-3} \mathrm{~m}^{2} \mathrm{~s}^{-1}$ which gives a mass diffusion length $\left(\sqrt{ } 4 \mathrm{~K}_{\mathrm{z}} \mathrm{t}\right)$ of only $8.3-$ $26.3 \mathrm{~m}$ over two days. Thus the SAS must be supplied by dissolution or exudation from sinking phytoplankton material. Even if the SAS were present as colloidal material in the samples they would need to be transported by particles to this depth as only Stokes settling of large organic particles $(0.1-1 \mathrm{~mm})$ would be fast enough to accomplish a descent of 100-200 $\mathrm{m}$ in 2 days or less. This implies then that the formation/release of SAS was very rapid during this time as part of the bloom began to sink out.

\subsection{Possible Composition, Sources and Sinks of SAS}

[13] SAS may be derived from a number of compounds including polysaccharides, proteins, humic acid and fulvic acid. Previous work using ONP detection of SAS has utilized changes in the height of the pre-peak of ONP to characterize the nature of the SAS present in the seawater [Gašparović and Cosović, 1995]. Using the same approach here it appeared that the initial SAS was strongly dominated by neutral polysaccharide components: consistent with results from a phytoplankton bloom in the Adriatic [Gašparović et al., 1998a] and culture studies with the diatom Phaeodactylum tricornutum [Gašparović et al., 1998b]. During day 31-33, when the EIFEX bloom was beginning to collapse, ONP pre-peak data suggested that while polysaccharides were still dominant, lipid and/or acidic polysaccharide material was also making a contribution to the SAS pool. Comparisons with measurements of total mono and polysaccharides and dissolved organic carbon (DOC) from EIFEX (S. Steigenberger, Role of TEP during EIFEX, manuscript in preparation, 2007) showed no apparent relationship with SAS, though this might be expected since surface active polysaccharides may contribute only a small fraction of the total polysaccharide or DOC pools.

[14] The most likely source, for SAS during EIFEX is from exudation products from diatoms which may be released under a variety of physiological stresses including nutrient/light limitation [Ignatiades and Fogg, 1973; Mopper et al., 1995; Waite et al., 1995]. Furthermore integrated SAS levels in EIFEX do appear to be closely related to the total diatom biomass in the upper water column (Figure 2). An alternative mechanism for SAS release is zooplankton grazing on diatoms [Kujawinski et al., 2002], we examined this further during EIFEX by undertaking a small scale grazing experiment with individual copepods, representative of the EIFEX patch [Jansen et al., 2006], collected close to the time of Station 580. Only Calanus propinquus showed a significant change with a tripling of SAS levels $\left(0.006\right.$ to $0.020 \mathrm{mg} \mathrm{L}^{-1}$ Triton X-100 eq), while experiments with individual Calanus simillimus and Pleuromamma showed no change in SAS over 24 hours, as did control samples with no copepods present. No experiments were conducted with protozoans. Whether the results here can be attributable to species or simply to the physiological status of the individual zooplankton is beyond the scope of the present work.

[15] The sink terms for SAS are less clear however; the components of SAS may be utilized by bacteria, altered by photochemistry, adsorbed on particles or accumulated on rising bubbles which either transport it to the microlayer or form TEP in situ [Azetsu-Scott and Passow, 2004; Zhou et al., 1998]. From the limited data set we have here it is not possible to determine what the major loss term for SAS was in the water column.

\subsection{SAS and Sticky Diatoms}

[16] An interesting feature at the time of the bloom collapse was the apparent increase in "sticky" diatoms, as defined by the observation of attached cellular debris to diatom chains, most notably Pseudo-nitzschia sp (Figure 2) mostly as P. lineola, P. turgidula, and P. turgiduloides. Most of the material attached to these diatoms possibly originated from crustacean fecal pellets as suggested earlier in studies from the Pacific Ocean [Buck and Chavez, 1994]. The maximum in "sticky" diatoms occurs some day after the apparent maxima in integrated SAS in the water column (Figure 2) - though as Buck and Chavez noted previously it may take several days for cells to divide and the diatom chains to lengthen after initial attachment to the fecal pellet. Diatoms are also well known to produce sugar containing compounds on their cell surfaces which modify their stickiness and thus their aggregation behavior [Waite et al., 1995]. Additionally some 
species of Pseudo-nitzschia are known to produce the toxin domoic acid as a low affinity uptake system for $\mathrm{Fe}$ and $\mathrm{Cu}$ [Wells et al., 2005], raising the possibility a significant part of the SAS activity may have been from compounds produced in response to increasing iron stress, light limitation, or as a grazing defense as the bloom progressed.

\section{Conclusions}

[17] The temporal changes of SAS during an open ocean iron induced phytoplankton bloom are reported for the first time. SAS levels increased during the course of the experiment and often appeared to be highest in regions of density discontinuities, presumably from material accumulation. This initial study highlights the need for more work focused on elucidating the molecules that make up SAS in seawater and their sources and sinks. Processes involving SAS in the sea surface microlayer may influence the air-sea exchange of climate important gases and aerosols and it is to the microlayer that future work should be concentrated; despite the technological challenge that must be faced for microlayer sampling under the sea conditions typically encountered in the Southern Ocean.

[18] Acknowledgments. The authors would like to show their deep thanks and appreciation to the crew of the R.V. Polarstern, for all their efforts in helping us throughout ANTXXI-3. Thanks also to the Chief Scientist, Victor Smetacek and to the AWI for making this cruise possible. This work was in part supported by a DFG grant awarded to P. Croot (CR145/4-1) and U. Passow (PA424/6-1). This work is a contribution to the German SOLAS (SOPRAN) program.

\section{References}

Azetsu-Scott, K., and U. Passow (2004), Ascending marine particles: Significance of transparent exopolymer particles (TEP) in the upper ocean, Limnol. Oceanogr., 49, 741-748.

Brainerd, K. E., and M. C. Gregg (1995), Surface mixed and mixing layer depths, Deep Sea Res., Part I, 42, 1521-1543.

Buck, K. R., and F. P. Chavez (1994), Diatom aggregates from the open ocean, J. Plankton Res., 16, 1449-1457.

Cisewski, B., V. H. Strass, and H. Prandke (2005), Upper-ocean vertical mixing in the Antarctic polar front zone, Deep Sea Res., Part II, 52, $1087-1108$

Frew, N. M., J. C. Goldman, M. R. Dennett, and A. S. Johnson (1990), Impact of phytoplankton-generated surfactants on air-sea gas exchange, J. Geophys. Res., 95, 3337-3352.

Gašparović, B., and B. Ćosović (1994), Electrochemical estimation of the dominant type of surface-active substances in seawater samples using onitrophenol as a probe, Mar. Chem., 46, 179-188.

Gašparović, B., and B. Cosović (1995), Electrochemical reduction of onitrophenol as a tool for the rough characterization of organic matter in seawater samples, Electroanalysis, 7, 1136-1142.

Gašparović, B., and B. Ćosović (2001), Distribution of surface-active substances in the northern Adriatic Sea, Mar. Chem., 75, 301-313.

Gašparović, B., V. Vojvodić, and B. Cosović (1997), Characterization of organic matter in fractionated seawater samples using o-nitrophenol as an electrochemical probe, Anal. Chim. Acta, 338, 179-190.

Gašparović, B., V. Vojvodić, and B. Ćosović (1998a), Excretion of organic matter during an experimental phytoplankton bloom followed using o-nitrophenol as an electrochemical probe, Croat. Chem. Acta, 71, 271284.

Gašparović, B., B. Ćosović, and V. Vojvodić (1998b), Contribution of organic acids to the pool of surface active substances in model and marine samples using o-nitrophenol as an electrochemical probe, Org. Geochem., 29, 1025-1032.

Gašparović, B., M. Plavsic, B. Ćosović, and M. Reigstad (2005), Organic matter characterization and fate in the sub-arctic Norwegian fjords during the late spring/summer period, Estuarine Coastal Shelf Sci., 62, 95-107.

Hardy, J. T., C. W. Apts, E. A. Crecelius, and G. W. Fellingham (1985), The sea-surface microlayer: Fate and residence times of atmospheric metals, Limnol. Oceanogr., 30, 93-101.
Hillebrand, H., C. D. Durselen, D. Kirschtel, U. Pollingher, and T. Zohary (1999), Biovolume calculation for pelagic and benthic microalgae, J. Phycol., 35, 403-424.

Hoffmann, L., I. Peeken, K. Lochte, P. Assmy, and M. Veldhuis (2006), Different reactions of Southern Ocean phytoplankton size classes to iron fertilisation, Limnol. Oceanogr., 51, 1217-1229.

Hunter, K. A. (1980), Processes affecting particulate trace metals in the sea surface microlayer, Mar. Chem., 9, 49-70.

Hunter, K. A., and P. S. Liss (1981), Polarographic measurement of surfaceactive material in natural waters, Water Res., 15, 203-215.

Ignatiades, L., and G. E. Fogg (1973), Studies on the factors affecting the release of organic matter by Skeletonema costatum (Greville) Cleve in culture, J. Mar. Biol. Assoc. U. K., 53, 937-956.

Jansen, S., C. Klaas, S. Krägefsky, L. von Harbou, and U. Bathmann (2006), Reproductive response of the copepod Rhincalanus gigas to an iron-induced phytoplankton bloom in the Southern Ocean, Polar Biol., $29,1039-1044$

Kujawinski, E. B., J. W. Farrington, and J. W. Moffett (2002), Evidence for grazing-mediated production of dissolved surface-active material by marine protists, Mar. Chem., 77, 133-142.

MacIntyre, S., A. L. Alldredge, and C. C. Gotschalk (1995), Accumulation of marine snow at density discontinuities in the water column, Limnol. Oceanogr., 40, 449-468.

Menden-Deuer, S., and E. J. Lessard (2000), Carbon to volume relationships for dinoflagellates, diatoms, and other protist plankton, Limnol. Oceanogr., 45, 569-579.

Mopper, K., J. A. Zhou, K. S. Ramana, U. Passow, H. G. Dam, and D. T. Drapeau (1995), The role of surface-active carbohydrates in the flocculation of a diatom bloom in a mesocosm, Deep Sea Res., Part II, 42, 47-73.

Passow, U. (2000), Formation of transparent exopolymer particles, TEP, from dissolved precursor material, Mar. Ecol. Prog. Ser., 192, 1-11.

Passow, U., A. L. Alldredge, and B. E. Logan (1994), The role of particulate carbohydrate exudates in the flocculation of diatom blooms, Deep Sea Res., Part I, 41, 335-357.

Peeken, I., et al. (2005), Export of fresh algal material during the Southern Ocean iron fertilisation experiment, EIFEX, paper presented at Summer Meeting 2005, Am. Soc. of Limnol. and Oceanogr., Santiago de Compostela, Spain, 19-24 June.

Röttgers, R., F. Colijn, and M. Dibbern (2005), Algal physiology and biooptics, Ber. Polarforsch. 500, pp. 82-88, Alfred Wegener Inst. für Polar und Meeresforsch., Bremerhaven, Germany.

Shine, J. P., and G. T. Wallace (1996), Flux of surface-active organic complexes of copper to the air-sea interface in coastal marine waters, J. Geophys. Res., 101, 12,017-12,026.

Smetacek, V., et al. (2005), The expedition ANT XXI/3 of R/V Polarstern, Ber. Polarforsch. 500, pp. 1-134, Alfred Wegener Inst. für Polar und Meeresforsch., Bremerhaven, Germany.

Strass, V., B. Cisewski, S. Gonzalez, H. Leach, K.-D. Loquay, H. Prandke, H. Rohr, and M. Thomas (2005), The physical setting of the European Iron Fertilization Experiment 'EIFEX' in the Southern Ocean, Ber. Polarforsch. 500, pp. 15-46, Alfred Wegener Inst. für Polar und Meeresforsch., Bremerhaven, Germany.

Tsai, W., and K. Liu (2003), An assessment of the effect of sea surface surfactant on global atmosphere-ocean $\mathrm{CO}_{2}$ flux, J. Geophys. Res. 108(C4), 3127, doi:10.1029/2000JC000740.

Utermöhl, H. (1958), Zur Vervollkommung der quantitativen PhytoplanktonMethodik, Mitt. Int. Ver. Theor. Angew. Limnol., 9, 1-38.

Waite, A. M., R. J. Olson, H. G. Dan, and U. Passow (1995), Sugarcontaining compounds on the cell surfaces of marine diatoms measured using concanavalin A and flow cytometry, J. Phycol., 31, 925-933.

Wallace, G. T. (1982), The association of copper, mercury and lead with surface-active organic matter in coastal seawater, Mar. Chem., 11, 379-394.

Wells, M. L., C. G. Trick, W. P. Cochlan, M. P. Hughes, and V. L. Trainer (2005), Domoic acid: The synergy of iron, copper, and the toxicity of diatoms, Limnol. Oceanogr., 50, 1908-1917.

Zhou, J., K. Mopper, and U. Passow (1998), The role of surface-active carbohydrates in the formation of transparent exopolymer particles by bubble adsorption of seawater, Limnol. Oceanogr., 43, 1860-1871.

Zutic, V., B. Cosović, E. Marcenko, and N. Bihari (1981), Surfactant production by marine phytoplankton, Mar. Chem., 10, 505-520.

P. Assmy, S. Jansen, U. Passow, and V. H. Strass, Alfred Wegener Institute for Polar and Marine Research, Am Handelshafen 12, D-27570 Bremerhaven, Germany.

P. L. Croot, Forschungsbereich Marine Biogeochemie, Leibniz-Institut für Meereswissenschaften at University of Kiel, Dienstgebäude Westufer, Düsternbrooker Weg 20, D-24105 Kiel, Germany. (pcroot@ifm-geomar.de) 